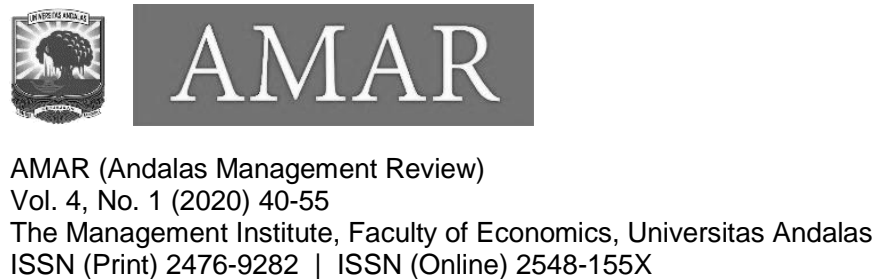

ISSN (Print) 2476-9282 | ISSN (Online) 2548-155X

\title{
The Effect of Religiosity Moderation with Loss Aversion on the Investment Decision of Personal Investors Kind of Stock Security in Padang City
}

\author{
Syailendra Eka Saputraa, Rizky Natassiab ${ }^{b}$ Hayu Yolanda Utamic \\ $a, b, c$ Economic Education Study Program STKIP PGRI West Sumatra, syailend_ra@yahoo.com
}

\begin{abstract}
This study aims to determine the effect of the value of religiosity that moderates loss aversion on investment decisions taken by individual investors in investing in stock type securities. The study was conducted on 120 individual investors who were chosen at random. The analytical method used is to use moderation analysis which is processed using Smart PLS. The test results found that religiosity does not affect the investment decisions of individual investors on stock type securities, while the loss aversion affects the investment decisions of individual investors on stock type securities. During the hypothesistesting phase, it was proven that religiosity moderation with loss aversion had a negative and significant influence on the investment decisions of individual investors in the securities of shares in Padang.
\end{abstract}

Keyword: Religiosity, Loss Aversion, Investment Decision

\section{INTRODUCTION}

Investment is an activity that is used by many community members to take advantage of the excess funds they have to optimize the benefits gained in the long run. For members of the investment community is considered more profitable, because if the excess funds are only kept at home or paid idle certainly will not benefit individuals who have funds, even the risk faced by investors will be even higher, even though investment activities are only carried out by some community members, while most others prefer to save money manually at home or in certain places.

According to Tandelilin (2012) investment is an activity that involves several individuals or groups of individuals who have excess funds with parties who have needs, where those who have excess funds are willing to invest the excess funds they have to meet the needs of certain party funds, preceded by the agreement between the two mutually beneficial parties. Investment activities are carried out in various ways, one of them by buying securities. 
According to Ross (2014), security is a collection of securities that can be traded to parties who have excess funds or are called investors. One of the securities offered to investors is shares. To carry out investment activities, investors, especially those from community members, can use financial institution services such as the capital market or other official institutions.

Along with technological advancements and increasingly vigorous activities carried out by financial institutions, especially capital markets and underwriters to promote investment, especially those carried out by buying several securities, especially stocks, have begun to attract the attention of the public so that the number of people participating in investing in securities continues to increase. This can be seen from the increasingly uncertain value of market capitalization that comes from public funds entering the Indonesia Stock Exchange.

Increased public participation in the context of investing in securities, especially stocks, indicates that there is a public understanding of financial flow. However, increasing public understanding of many financial iterations is also hampered by the perception that states that investments in several securities are acts that are prohibited by religion, in addition to investing in shares also carry a high risk. Various information and issues related to stock investment activities will form an emotional bias and the value of religiosity owned by each individual, so it is suspected that it will influence them to invest.

According to Pradhana (2018) emotional bias is one of the factors that influence investment decisions to be taken by investors. Emotional bias shows that there are emotional considerations in investors that will influence them to invest. Emotional bias can be observed from three dimensions, namely, loss aver aversion, regret aversion bias, and the status quo. Each dimension shows the psychological that investors have in investing, especially in stock securities. Management on three dimensions of emotional bias will affect each investor's decision to invest.

Tandelilin (2012) defines loss aversion as a psychological condition of potential investors who are afraid of facing risks so they are likely to avoid risk. In general, these investors will be very careful about investing. Besides that, the tendency of investors with emotional loss aversion will decide by buying shares of large companies with relatively good performance and playing for the long term and tends to avoid speculation. By the concise description, the researchers suspect that the emotional bias that is measured by loss aver aversion affects the decision of investors to invest in security, especially stocks. 
Besides emotional bias, investors' investment decisions on stock securities can also be influenced by the religious value of an investor. According to Ghazali (2015) religiosities are related to the understanding one has of a certain belief in religion, which encourages the individual to stay away from all restrictions on that belief or religion. The same thing certainly occurs in investment activities carried out by the public, the existence of a fatwa issued by the MUI is a factor that influences investors' decisions in investment securities, especially stocks. Given the investment activities there are dividends, returns, or other benefits that are considered to have the value of usury which is considered haram by Islam. Thus the researchers suspect that the religious value and emotional bias of an investor which is observed from the loss aversion is the deciding factor in the formation of their investment decisions on stock type securities.

\subsection{Literature Reviews}

\section{a. Effect of Loss Aversion on Investment Decisions}

Tandelilin (2012) emotional bias shows emotional responses that arise from within investors before making investment decisions, especially in the form of stock type securities. Emotional bias shows more fears or worries that arise from the individual before deciding to invest in stock securities. Emotional bias can be in the form of rejection of the risks to be faced, the courage to overcome the risk, or euphoria that arises in investors before investing.

Agustin and Mawardi (2014) found that loss aversion has a positive effect on investment decisions. The results obtained indicate the higher fear in investors in investing will encourage them to be careful in making decisions. The process is carried out by searching for information relating to the company for which it is intended, analyzing risks and creating a portfolio of shares, when investors assess the risks they face are relatively high then the possibility of an investor's decision to invest will be weaker.

Pradhana (2018) found that loss aversion has a positive effect on investment decisions in investors. Increasingly afraid of investors to face risks in investing will weaken an investor's decision to invest. Loss aver aversion will encourage investors to be careful and guarantee the completeness of information before deciding to invest. The higher risk will increase the likelihood of investors getting a loss from the investment activities they do, therefore when the risk is high their willingness to invest will decrease. Based 
on the concise description that has been explained, then a hypothesis will be proposed, namely: $\mathrm{H}_{1}$ Loss aversion has a significant effect on investment decisions

\section{b. The Effect of Religiosity on Investment Decisions}

Fuad et al. (2018) found that religiosity has a negative effect on investment decisions in the form of securities, especially stocks. A Muslim will tend to avoid trading that is speculative and usury, so in choosing their business activities tend to avoid investing in shares. In general, investors who have high religious values will seek halal investments such as buying or using sharia trading products.

El-Gohary (2016) found that religiosity has a negative effect on investment decisions to be implemented. The results obtained show that when an investor is a devout Muslim they will avoid investment activities that are contrary to religion, where they will try to trade in other forms, and in accordance with Islamic teachings or sharia. The decline in the desire of Muslim investors to invest in shares is due to the existence of an element of usury

Rahman et al (2015) define religiosity as a concept of behavior carried out by someone based on the values of belief or religion. Religiosity in question is related to the development of Islamic religious values in behavior in daily life. In the study of the concept of religiosity is more intended for the selection of food products, in this case, the selection of food products intended to the extent that each individual considers halal and illicit food products, so that they can controlling behavior so as not to buy food products that are forbidden by Islamic religious values. Based on the description of a number of previous research results that have been described, then a hypothesis is proposed that will be proven, namely: $\mathrm{H}_{2}$ Religiosity has a significant effect on investment decisions

\section{c. The Effect of Religiosity on Risk Aversion and Investment Decision}

Fuad et al. (2018) stated that religion or belief held by an investor tends to prohibit securities investment activities, bearing in mind that these activities are speculative activities that contain interest rates, in addition to that investment activities can also result in the risk of loss to investors who make investments. The description is also supported by El-Gohary (2016) and Rahman et al (2015) which states that religious 
considerations often encourage someone to cancel an investment activity that will be carried out by an investor, the decision will be heavier when the investment risk faced is also higher.

The results of Mahdzan et al. (2017) stated that investors' religiosity and psychological fear of facing risks will reduce their desire to invest, especially in stock type securities. Religious teachings that forbid speculation through investing because it contains the value of usury and risk that harms the culprit will reduce the desire of Muslim investors to invest, especially in stock type securities. Based on a brief description of a number of previous research results that have been described above, then a hypothesis is proposed that will be proven in this study, namely:

$\mathrm{H}_{3} \quad$ Religiosity has a significant effect on investment decisions

$\mathrm{H}_{4} \quad$ Religiosity moderate the loss aversion has a significantly effect on investment decisions

Based on the description of the theory and several of previous research results, it can be proposed a conceptual framework model that will be gui ded in the hypothesis testing stage in this study, namely:

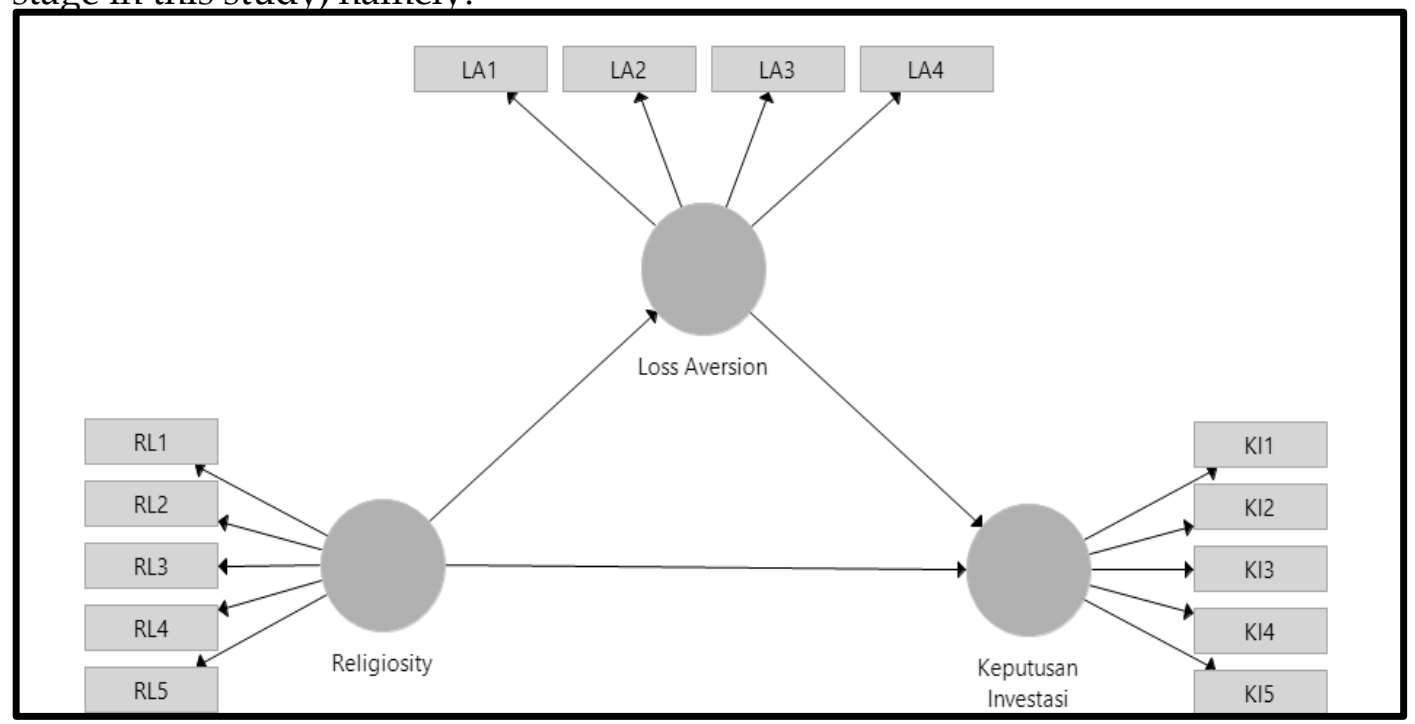

Figure 1. Thinking Framework Model

Source: Statistical data processing (2020)

\section{METHOD}

In this study, the population is investors who have carried out investment activities in the form of securities through financial institutions or underwriters in the city of Padang. In narrowing the scope of the study, the sample used is some investors 
who have carried out investment activities in the form of securities, especially shares in financial institutions or securities intermediaries in the city of Padang. Since the population size is not known with certainty or is not limited, the sample size is chosen by citing the opinion of Roscoe (1994) in Sekaran (2014) which states that the exact sample size is at least 10 times the number of variables, wherein the study the number of multipliers that the researchers determined was 20 so the number or size of the sample used is $20 \times 5,100$ investors investing in stock securities in several financial institutions or securities brokers in the city of Padang.

To get the right sample size, the researchers used a purposive sampling method. According to Sugiyono (2014) purposive sampling is a sampling method that is based on some special criteria intended to limit the number of populations selected as samples. The criteria used include:

a. Individual investors who conduct investment activities in the form of stock securities and domiciled in the City of Padang.

b. Investors who have confidence according to Islam.

The research variables used can be grouped into three namely endogenous variables namely investment decisions, exogenous variables namely religiosity and moderation variables are loss aversion. In order to test the hypothesis it is carried out using the help of the Smart PLS program version 3.27.

The data processing stage starts from testing the research instrument through outer loading analysis, where each statement item that supports the variable must have an outer loading coefficient above 0.70 (Hair et al., 2010), perform reliability testing by looking for Cronbach's Alpha values> 0.70 (Hair et al., 2010), Construct Reliability > 0.70 (Hair et al., 2010) and Average Variance Extracted> 0.50 (Hair et al., 2010). The next stage is testing the cross loading matrix, testing the accuracy of the model through the coefficient of determination, and testing the direct and indirect effects. A hypothesis is declared influential when it has a P-value below the level of confident 5\% (Hair et al., 2010). 


\section{RESULTS AND DISCUSSION}

\subsection{Demographics of Respondents}

This study aims to prove the effect of religiosity on investment decisions through loss aversion as a moderating variable. The study was conducted on several community members who had invested in securities in the form of shares, through official institutions. In this study as many as 120 individual investors were chosen randomly. Following the identification of data that has been done can be narrated respondents' demographics as shown in Table 1 below:

Table 1

Demographics of Respondents

\begin{tabular}{lcc}
\hline \multicolumn{1}{c}{ Information } & Sum & Percentage \\
\hline Gender & 78 & \\
Man & 42 & 65.00 \\
Woman & & 35.00 \\
\hline Age & 36 & \\
$21-30$ Years & 13 & 30.00 \\
31 - 40 Years & 47 & 10.83 \\
41 - 50 Years & 19 & 39.17 \\
$51-60$ Years & 5 & 15.83 \\
>60 Years & & 4.17 \\
\hline Occupation & 5 & \\
Lecturer & 7 & 4.17 \\
Teachers / Teaching Staff & 19 & 5.83 \\
College student & 32 & 15.83 \\
Private employees & 41 & 26.67 \\
Entrepreneur & 4 & 34.17 \\
POLRI & 12 & 3.33 \\
Others & & 10.00 \\
\hline Investment Objectives & 21 & \\
Study & 4 & 17.50 \\
Look for experience & 13 & 3.33 \\
Learning to Manage Risk & 42 & 10.83 \\
Maximizing Profits & 7 & 35.00 \\
Trying & 23 & 5.83 \\
Take advantage of excess data & 10 & 8.17 \\
Speculation & 120 & 100 \\
\hline Total & &
\end{tabular}

Source: Statistical data processing (2020)

In Table 1, it can be seen that the majority of respondents are male gender, ie $65 \%$ of the total respondents while the remaining $35 \%$ are female. If observed from the age 
characteristics, the majority of respondents have ages between 41 years to 50 years which amounted to $39.17 \%$ while the respondents with the least number were those who were over 60 years old which amounted to $4.17 \%$ of the total of all respondents. Following the data tabulation process it is also known that the majority of respondents work as entrepreneurs. The statement was recognized by $34.17 \%$ of the total respondents while the smallest number of respondents were those who were active as members of the Indonesian National Police, only $3.33 \%$. In the survey that has been done, it is known that the main reason that drives people to become investors and invest in stock type securities is to maximize profits that are $35 \%$ of the total respondents while the least number of respondents are those who have reasons to become investors to look for experience. The statement was recognized by $3.33 \%$ of the total respondents

\subsection{Measurement Model Assessment}

Tests are carried out to ensure that each statement item used to measure each variable is an accurate and reliable statement item. Based on the results of data processing carried out using the help of the Smart PLS program the results are shown in Table 2 below:

Table 2

Measurement Assessment Result Testing

\begin{tabular}{lcccc}
\hline \multicolumn{1}{c}{ Item Code } & $\begin{array}{c}\text { Outer } \\
\text { Loading }\end{array}$ & $\begin{array}{c}\text { Cronbach's } \\
\text { Alpha }\end{array}$ & $\begin{array}{c}\text { Construct } \\
\text { Reliability }\end{array}$ & AVE \\
\hline Investment Decision (KI) & 0.811 & & & \\
$\mathrm{KI}_{1}$ & 0.860 & & & \\
$\mathrm{KI}_{2}$ & 0.846 & 0.879 & 0.912 & 0.675 \\
$\mathrm{KI}_{3}$ & 0.785 & & & \\
$\mathrm{KI}_{4}$ & 0.804 & & & \\
$\mathrm{KI}_{5}$ & & & & \\
\hline Loss Aversion (LA) & 0.823 & & & \\
$\mathrm{LA}_{1}$ & 0.896 & 0.711 \\
$\mathrm{LA}_{2}$ & 0.859 & & & \\
$\mathrm{LA}_{3}$ & 0.790 & & & \\
$\mathrm{LA}_{4}$ & & & & \\
\hline Religiosity (RL) & 0.910 & & & \\
$\mathrm{RL}_{1}$ & 0.920 & & & \\
$\mathrm{RL}_{2}$ & 0.882 & 0.937 & & \\
$\mathrm{RL}_{3}$ & 0.915 & & & \\
$\mathrm{RL}_{4}$ & 0.840 & & & \\
$\mathrm{RL}_{5}$ & & & & \\
\hline Source: Statistical data processing $(2020)$ & & & \\
\end{tabular}


Following the test results, it can be seen that each statement item used to measure investment decision variables, loss aversion, and religiosity already have an outer loading coefficient above 0.70 (Hair et al, 2010) also each variable already has a Cronbach's Alpha value above or equal to 0.70 Besides that in the data processing stage also obtained the value of Construct Reliability which is owned by each variable has been above 0.70 and the Average Extracted (AVE) value is above 0.50. Thus it can be concluded that all research variables used have been supported by appropriate and reliable statement items so that further data processing stages can be carried out immediately.

\subsection{Discriminant Validity}

The discriminant validity test aims to ensure that the research variables used are supported by the appropriate statement items. Based on the results of the discriminant validity test, a summary can be seen in Table 3 below:

Table 3

Discriminant Validity Testing Result

\begin{tabular}{lccc}
\hline & $\begin{array}{c}\text { Investment } \\
\text { Decision }\end{array}$ & $\begin{array}{c}\text { Loss } \\
\text { Aversion }\end{array}$ & Religiosity \\
\hline Investment Decision & 0.822 & & \\
Loss Aversion & 0.886 & 0.843 & \\
Religiosity & 0.812 & 0.708 & 0.894 \\
\hline Source: Statistical data processing & $(2020)$ & &
\end{tabular}

Source: Statistical data processing (2020)

Following with the test results, it can be seen that each variable has a greater discriminant validity coefficient than the variables that are below or to the right of the variable matrix so that it can be concluded that all research variables used have been supported by the right statement items. Therefore further stages of data processing can be done immediately.

\subsection{Cross Loading}

Hair et al. (2010) defines cross-loading as a matrix which shows that the statement items used in measuring each variable are appropriate. Following the data processing, the results are shown in Table 4 below: 
Table 4

Cross Loading Result Testing

\begin{tabular}{lccc}
\hline & $\begin{array}{c}\text { Investment } \\
\text { Decision }\end{array}$ & Loss Aversion & Religiosity \\
\hline KI1 & 0.811 & 0.722 & 0.725 \\
\hline KI2 & 0.860 & 0.747 & 0.710 \\
\hline KI3 & 0.846 & 0.776 & 0.718 \\
\hline KI4 & 0.785 & 0.658 & 0.528 \\
\hline KI5 & 0.804 & 0.730 & 0.642 \\
\hline LA1 & 0.683 & 0.823 & 0.787 \\
\hline LA2 & 0.767 & 0.896 & 0.834 \\
\hline LA3 & 0.797 & 0.859 & 0.814 \\
\hline LA4 & 0.738 & 0.790 & 0.609 \\
\hline RL1 & 0.709 & 0.775 & 0.910 \\
\hline RL2 & 0.642 & 0.760 & 0.920 \\
\hline RL3 & 0.706 & 0.818 & 0.882 \\
\hline RL4 & 0.759 & 0.854 & 0.915 \\
\hline RL5 & 0.800 & 0.838 & 0.840 \\
\hline Source: Statistical data processing (2020) & &
\end{tabular}

The base of the results of cross loading testing, it can be seen that each variable has been supported by statement items that have a correlation coefficient higher than the value of the variable correlation coefficient to the right so that it can be concluded that each study variable used in this study has been supported by the right statement items. Therefore further stages of data processing can be done immediately.

\subsection{R-Square}

The coefficient of determination analysis aims to find out how precisely the research variables used can predict changes in endogenous variables used by percentages (Hair et al. 2010). In this study, two sub-structure models that have different contribution results are as shown in Table 5 below:

Table 5

R-Square Testing Result

\begin{tabular}{lc}
\hline \multicolumn{1}{c}{ Model } & R-Square \\
\hline Investment Decision & 0.785 \\
\hline Loss Aversion & 0.826 \\
\hline Source: Statistical data processing (2020) &
\end{tabular}

In Table 5 it can be seen that the inner model used in this study has two substructures. The first sub-structure shows that the religiosity variable contributes to affect the loss aversion of 0.825 or $82.50 \%$ while the remaining $17.50 \%$ is explained by other variables outside the current research model. In the second sub-structure model shows that the loss aversion and religiosity have a contribution in influencing the investment 
decisions of investors in the city of Padang on the type of stock securities amounting to 0.785 or $78.50 \%$. The coefficient of determination obtained in the two sub-structures shows the inner model formed in a structural framework model is appropriate

Thus it can be concluded that the sub-structure model that forms the structural framework in this study is appropriate or fit. Structural framework or the so-called inner model formed from a combination of research variables used in this study can be seen in Figure 2 below:

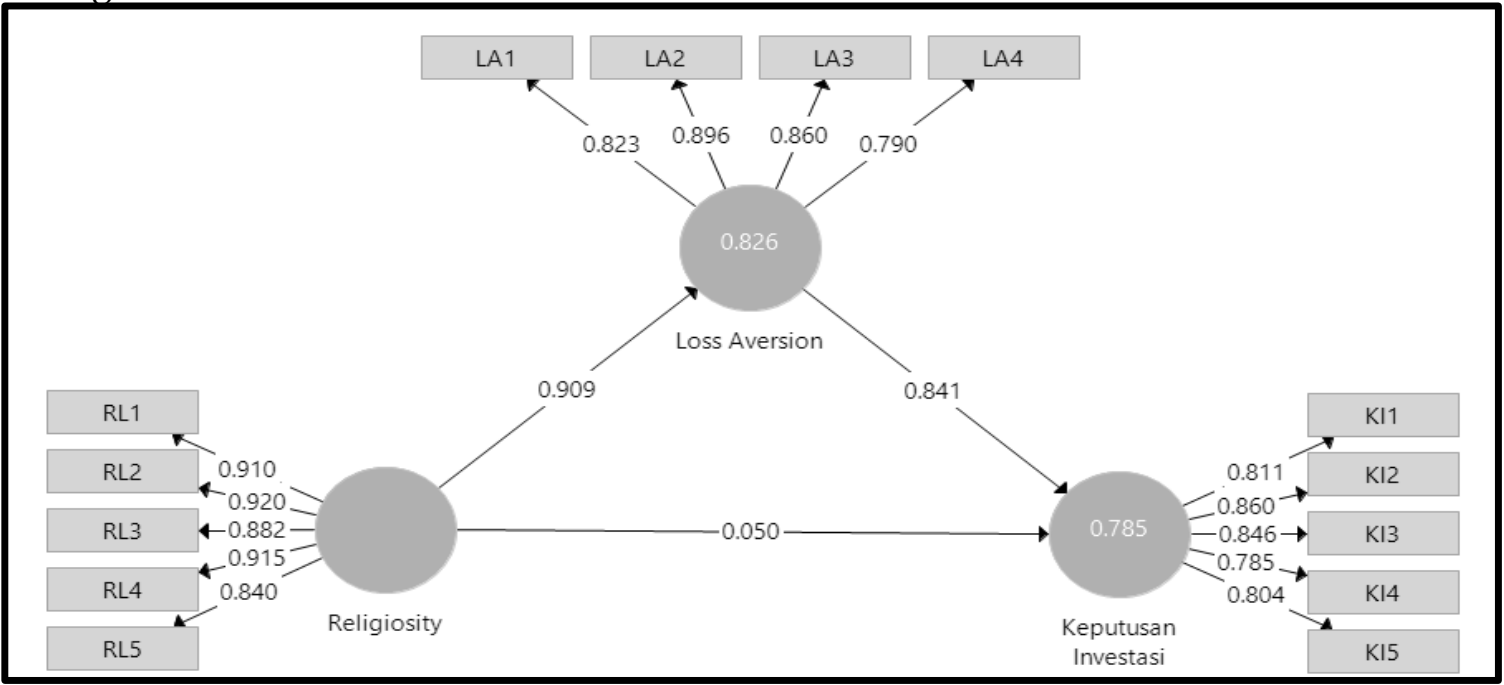

Figure 2. Structural Model

Source: Statistical data processing (2020)

\subsection{Hypothesis Testing Result}

This study aims to prove the influence of religiosity which is moderated by loss aversion on investor investment decisions that come from the public (public) in the city of Padang. Based on the results of data processing, a summary of the results can be seen in Table 5 below:

Table 6

Summary of Hypothesis Testing Results

\begin{tabular}{lcccc}
\hline \multicolumn{1}{c}{ Testing Model } & $\begin{array}{c}\text { Path } \\
\text { Coefficient }\end{array}$ & t-statistic & P-value & Conclusion \\
\hline LA -> KI & 0.728 & 4.582 & 0.000 & Accepted \\
RL-> KI & 0.068 & 0.441 & 0.660 & Non Accepted \\
RL -> LA & 0.909 & 29.784 & 0.000 & Accepted \\
RL*LA -> KI & -0.130 & 3.014 & 0.003 & Accepted \\
\hline
\end{tabular}

Source: Statistical data processing (2020)

Based on the results of the first hypothesis testing, it can be seen that the loss aversion (LA) has a path coefficient of 0.728 to the investment decision (KI) which is 
statistically proven with a P-value of 0,000 . The P-value obtained is far below the 0.05 confidence level so that it can be concluded that the loss aversion has a positive effect on investors' decisions to invest in stock type securities in Padang.

The findings obtained indicate that the fear that investors have at risk in carrying out investment activities actually drives their desire to invest in shares. The results obtained are in line with the theory explained by Tandelilin (2012) which states that the more daring an investor is to put aside the fear they have in investing, the higher the profits they will obtain. Similar results were also obtained by Mahdzan et al., (2017) and the same study conducted by Jia et al (2017) found that the fear of investing actually made most investors psychologically prepared to invest due to face their risks. has collected various completeness of data and information including making a stock portfolio.

In the second hypothesis testing stage, it can be seen that religiosity (RL) has a weak influence on investment decisions (KI) of 0.068 which is statistically proven through a P-value of 0.660 which is far above the 0.05 confidence level so that it can be concluded that religiosity has no effect significant impact on investment decisions of investors in the city of Padang, especially in stock type securities. Thus the second hypothesis is rejected. The findings obtained show that trust is not the main consideration for investors to decide to invest in certain securities, especially stocks. In this case investors see their main orientation in investing is profit, thus encouraging most investors to ignore the value of religion in making investment decisions, especially in stock type securities. The results obtained are supported by research Nigam et al., (2018) who found that religiosity has no effect on investment decisions made by investors in stock type securities.

The base of the third hypothesis testing stage, it can be seen that religiosity influences the loss aversion of 0.909 , which is proven statistically with a P-value of 0,000 which is far below the confidence level of 0.05 . to investors who are in the city of Padang. The results obtained indicate that the higher the religious considerations, the more risk will be faced in investing. When investors face greater risk in investing, they will tend to postpone the decision or look for risk-free investments such as buying government bonds or saving. These findings are supported by research conducted by 
Fuad et al. (2018), El-Gohary (2016) and Rahman et al. (2015) which states that religious considerations often encourage a person to cancel an investment activity that will be carried out by an investor, the decision will be more severe when investment risks faced are also increasingly high.

The fourth hypothesis aims to prove the existence of the moderating effect between religiosity and loss aversion on investment decisions that can be seen in the inner model framework shown in Figure 3 below:

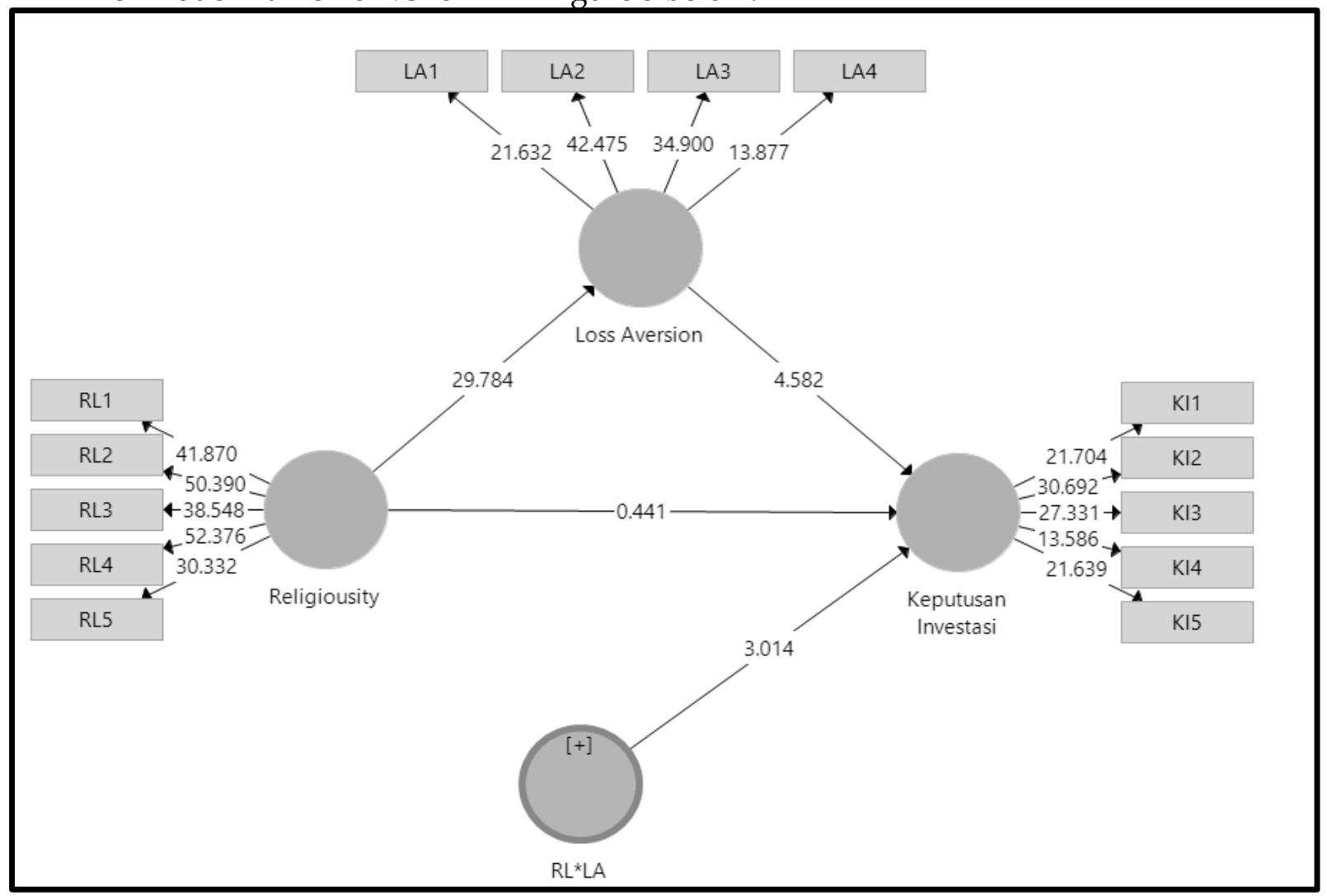

Figure 3. Inner Model Hypothesis Effect Moderation Testing

Source: Statistical data processing (2020)

In the fourth stage of testing the hypothesis it appears that the moderation between religiosity and loss aversion can give an influence on investment decisions of 0.130. The coefficient value is statistically proven with a t-statistic value of 3.014 or Pvalue of 0.003 which is far below the 0.05 confidence level thus it can be concluded that the moderation between religiosity with loss aversion has a negative and significant effect on investment decisions made by investors in Kota Padang in stock type securities. These results indicate the factor of trust in a religion and the fear in investors of many risks that can cause losses will reduce the desire of investors in the city of 
Padang to invest in securities in the form of shares. The results obtained are in line with research by Fuad et al. (2018), El-Gohary (2016), and Rahman et al. (2015) which states that investors' religiosity and psychological fear of facing risks will reduce their desire to invest, especially in stock type securities.

\section{CONCLUSION AND IMPLICATIONS}

\subsection{Conclusion}

Based on the results of testing the hypothesis that has been done, several important conclusions can be proposed, namely:

a. Loss aversion has a positive and significant effect on investors' decisions to invest in stock type securities in the city of Padang.

b. Religiosity does not significantly influence investor investment decisions in the city of Padang.

c. Religiosity has a positive and significant effect on loss aversion, especially in investing in stock types of securities in investors in the city of Padang

d. Religiosity with loss aversion has a negative and significant effect on investment decisions made by investors in the city of Padang on stock type securities.

\subsection{Implication}

In accordance with the results of testing the hypothesis that has been done, several implications that can be beneficial for:

a. For investors in investing, especially those who are afraid of facing risks are expected to make a portfolio to find out the possible return or risk to be faced in investing.

b. Investors are expected to be able to carry out technical or fundamental analysis to minimize the risks that will be faced and maximize the benefits that can be obtained

c. Diversification in investment activities must be carried out as a basis for minimizing the risk of loss by the investor. Diversification can be done by creating a separate stock portfolio based on the value of the risk to be faced.

\section{REFERENCE}

Pramita, A., \& Imron, M. (2014), “Perilaku Investor Muslim Dalam Bertransaksi Saham di Pasar Modal", JESTT, Vol. 1, No. 12. 
Muskaan, A., \& Kumari, S. (2015), "Risk Taking in Financial Decisions as a Function of Age, Gender: Mediating Role of Loss Aversion and Regret", International Journal of Applied Psychology 2015, Vol. 5, No. 4, pp. 83-89.

El-Gohary, dkk. (2017), "Understanding the Factors Affecting the Adoption of E-marketing by Small Business Enterprises", See Discussions, publication at: https://www.researchgate.net/publication/258257043.

Nugraha, F., Kurnia, R., dan Hayati (2018), “Analisis Pengaruh Bias Emosional terhadap Keputusan Investasi Investor Pemula di Kota Surakarta", Jurnal Bisnis dan Ekonomi Vol. 11, No. 2.

Imran, Ghazali (2015), Investasi dalam Konsep Islam, Ghalia, Jakarta.

Hair J. F., William C. B., Barry J. B., and Rolp E. A. (2010), Multivariate Data Analysis Data Analisys, Pearson, Prentice-Hall.

Fansheng, J., Zhang, Y., Chan, Kam. C., Xie, S. (2018), “The Impact of Religiosity on Corporate Loans and Maturity Structure: Evidence From China", Pacific Accounting Review.

Rafique, K. A., Azeem, M., and Sarwar, S. (2017), “Impact of Overconfidence and Loss Aversion Biases on Investment Decision: Moderating Role of Risk Perception", International Journal of Transformation in Accounting, Auditing \& Taxation, Vol. 1, Issue 1.

Mahdzan, Rozaimah N. S., Zainudin, Hashim R. C., \& Sulaiman N. A. (2017), “Islamic Religiosity and Portfolio Allocation: The Malaysian Context", International Journal of Islamic and Middle Eastern Finance and Management.

Misra, N. R., Srivastava, S., \& Banwet, D. K. (2017), “Behavioral Mediators of Financial Decision Making - A Meta-Analysis", Review of Behavioral Finance.

Widiar, Pradhana Rafinza (2018), “Pengaruh Financial Literacy, Cognitive Bias, Dan Emotional Bias Terhadap Keputusan Investasi (Studi Pada Investor Galeri Investasi Universitas Negeri Surabaya)", Jurnal Ilmu Manajemen, Vol. 6, No. 3.

Pujiyanto, N., dan Mahastanti, L. A. (2013), "Regret Aversion Bias dan Risk Tolerance dalam Keputusan Investasi", Journal \& Proceeding, Vol. 3, No. 1.

S, Rahman , H., Alamsyah , and Junaidy (2015), "Impact Emotional Characteristic on Investment Decision Muslim Investor in Malaysian", Economic International of Journal, Issue 12.

Jeff, Ross Westerfield. (2014), Corporate Finance, Ed. 9, Irwin, McGraw-Hill. 
Andalas Management Review, Vol. 4 No. 1, 2020

Sekaran, Uma (2013) Research Methods For Business (Metode Penelitian Untuk Bisnis), Jakarta: Salemba Empat.

Sartono, Agus (2012), "Dasar Dasar Manajemen Keuangan (Teori dan Aplikasi)", Yogyakarta, BPFE UGM. 